\title{
The sound of poetry
}

Previously published at www.cmaj.ca

\section{Silent Music}

Richard Bronson

Padishah Press; 2009.

I $f$ this collection of poems is any indication, it's clear that Richard Bronson can find music anywhere. In the title poem, "Silent Music," he enters his mother's apartment and hears, ticking from the radiators, the "anguished chord" that opens the third act of Tristan und Isolde. Now that's a musician's ear.

Bronson, a physician at the Stony Brook University Medical Center on Long Island in New York State, is unquestionably an accomplished poet; he was the 2003 recipient of the Poem of the Year award of the American College of Physicians. He has followed up his first collection of poems, Search for $\mathrm{Oz}$, with a second volume that explores his life and his world with ears wide open.

\section{Bronson brings a musician's ear into the world of poetry.}

The first section of Silent Music focuses on Bronson's childhood, youth and family. These poems avoid the sentimentality that one sometimes finds in such subjects. Instead, he gives the reader a taste of the joy and ebullience of youth - "I hotfooted on sun-baked sand, / ran off toward the water's edge / \& yelling 'Goolop, dee goolop!'” ("My Uncle Jerry") — or shows us what it's like to "plunge / toward the fast approaching light / at the end of the tunnel" on a wooden roller coaster ("The Mouth of the Dragon").

Music, in all its forms, is a consis-

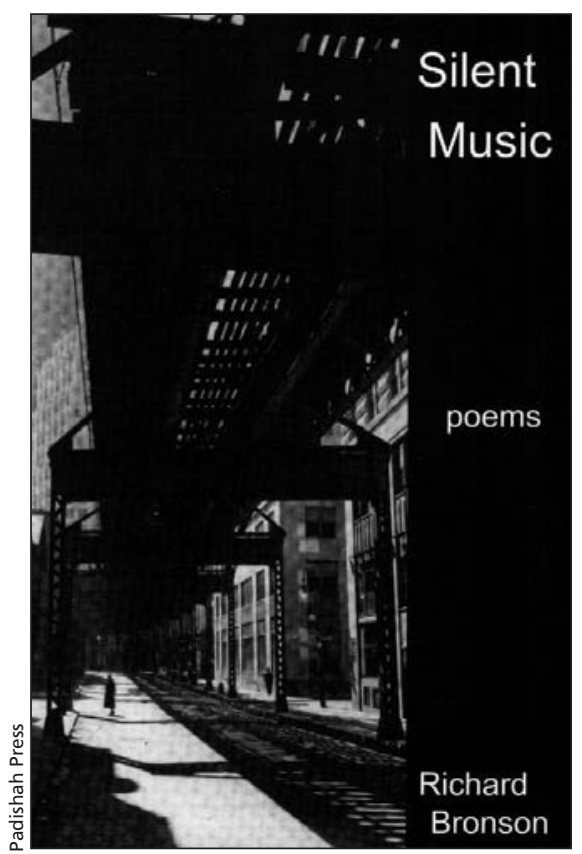

tent theme throughout these poems, including references to Wagner, Brahms and other composers; the A, $\mathrm{E}$ and $\mathrm{C}$ notes on a triad of wine goblets; and his father's violin, which he

finds abandoned in an attic and asks "Can you sing me a song / of my lost father"(www.cmaj.ca/cgi/doi/10.1503 /cmaj.081575). In "The Dinner Party," a particularly touching poem about loss and absence, he says his mother "would understand / the need for the minor chord."

The second section contains nine poems of travel and far off places, and takes us on journeys to Ecuador, Japan, Tewkesbury Abbey in England and Italy. These poems prove less engaging than those in the first section, although the author does success- fully contrast the eternal faith of the long-ago monks of Tewkesbury with his own "age of doubt."

In the third section, Bronson touches, in several poems, on his life as a doctor, sometimes wondering which head he will wear that day, the head of the poet or healer? In "Massacre of the Innocents," he mourns the destruction of three-thousand orphaned embryos, their little lives ending in "a whisper / of nitrogen vapor." In a number of these poems, however, he resorts too often to mythological references that distance the reader from the everyday intrigue of his profession.

In the last section, Bronson reveals his political side. He questions the wisdom in governments granting themselves emergency powers, ponders "the American way" after Abu Ghraib, and wonders why so much destruction has been deployed "in our name." The strongest poem in this section is the Rumi-like lyric, "The Man Who Raised Nightingales," a sad and lovely meditation on how a world of tender passion and gentle music is too often drowned out by the shriek of violence: "And the Wazir of the West / danced to the chant, in his very pointed shoes, / played duet on his oud, / cried 'Wallazoon, Aa' arooon!'

Altogether, Silent Music offers a good, though uneven, selection of poems. This reader longed for more exploration of the intersection between medicine and poetry, between healing and music (as well as silence). Perhaps a future volume will pry open this fertile territory.

\section{Mark Frutkin \\ Novelist and poet \\ Ottawa, Ont.}

Mark Frutkin has published 11 books. His latest novel, Fabrizio's Return (2006), won the Trillium Award for best book in Ontario and the Sunburst Award. 